\title{
Pemanfaatan Multimedia Sebagai Media Pembelajaran Untuk Meningkatkan Pemahaman Siswa Terhadap Materi Fisika Elektromagetik
}

\author{
Tyrza Adelia \\ Program Studi Teknik Informatika \\ Universitas Surabaya \\ tyrza@staff.ubaya.ac.id
}

\author{
Susana Limanto \\ Program Studi Teknik Informatika \\ Universitas Surabaya \\ susana@staff.ubaya.ac.id
}

\begin{abstract}
Abstrak - "Elektromagnetik" adalah salah satu mata pelajaran Fisika yang diajarkan di SMK. Materi ini sangat berguna untuk siswa karena banyak penerapan yang dapat dilakukan dalam kehidupan sehari-hari. Permasalahan yang muncul adalah siswa yang masih sulit memahami materi elektromagnetik dan rumusrumus terkait, serta membayangkan cara menerapkan materi elektromagnetik dalam kehidupan sehari-hari karena sistem belajar mengajar di sekolah yang menggunakan media konvensional seperti presentasi power point, buku, papan tulis, dan alat peraga. Untuk mengatasinya, dibuat media aplikasi multimedia pembelajaran yang dilengkapi dengan berbagai fitur. Aplikasi ini diharapkan dapat memberikan kemudahan untuk siswa dalam memahami materi dan rumus-rumus terkait, serta membayangkan cara menerapkan materi dalam kehidupan sehari-hari. Proses pembuatan aplikasi pembelajaran melalui penelitian dengan metode waterfall yang dimulai dengan mengumpulkan data. Data tersebut akan digunakan untuk merangkum permasalahan yang ada dan menentukan kebutuhan sistem aplikasi multimedia yang akan dibuat. Aplikasi ini melewati proses uji coba untuk memastikan aplikasi pembelajaran sudah bebas dari error (verifikasi) dan sesuai dengan kebutuhan pengguna (validasi). Validasi dilakukan dengan cara melakukan wawancara kepada tiga orang guru fisika SMK ' $X$ ' dan menyebarkan kuisioner kepada 20 orang siswa terkait dengan kemanfaatan aplikasi. Pengukuran dilakukan dengan melakukan pre-test dan post-test kepada 20 orang siswa. Soal yang digunakan untuk melakukan pre-test dan post-test diacak dari bank soal, masing-masing 10 soal untuk pre-test dan 10 soal untuk post-test. Hasil uji coba menunjukkan bahwa aplikasi pembelajaran dapat meningkatkan kemampuan siswa dalam memahami materi elektromagnetik dan rumus-rumus terkait, serta membantu memudahkan guru dalam penyampaian materi elektromagnetik. Hal ini terlihat dari adanya peningkatan sebesar $100 \%$ dari jumlah siswa yang mampu mengerjakan lebih banyak soal post-test dengan benar.
\end{abstract}

Kata Kunci: elektromagnetik, pembelajaran, multimedia.

\section{PENDAHULUAN}

Elektromagnetik merupakan salah satu materi dari pelajaran fisika dasar yang diajarkan di SMK [1][2]. Materi ini mempelajari tentang pergerakan magnet untuk menghasilkan listrik. Bagi siswa SMK, materi ini tergolong sulit karena mereka harus memahami rumus-rumus yang ada, sedangkan mereka tidak memiliki pemahaman dasar matematika yang kuat. Selama ini, pengajar di SMK ' $X$ ' menyampaikan materi dengan metode ceramah dengan menggunakan media power point, buku, dan papan tulis, serta metode praktek dengan menggunakan alat peraga.

Permasalahan yang muncul adalah siswa SMK masih sulit untuk memahami materi elektromagnetik serta membayangkan cara menerapkan materi elektromagnetik dalam kehidupan sehari-hari. Permasalahan lain dari sisi pengajar adalah pengajar masih kesulitan membuat siswa SMK memahami materi elektromagnetik dengan metode ceramah dengan media-medianya karena minim visualisasi. Sedangkan pengajaran dengan metode praktek juga memiliki kendala yaitu jumlah alat peraga yang terbatas untuk digunakan seluruh siswa di kelas yang mengakibatkan penyerapan materi tidak merata [3].

Untuk membantu proses belajar mengajar diperlukan suatu alat bantu yang tepat agar materi elektromagnetik ini dapat dengan mudah disampaikan oleh pengajar dan dipahami oleh siswa [4]. Alat bantu tersebut harus mendukung interaksi dalam proses belajar mengajar yang merupakan komponen terpenting dalam pembelajaran [5].

Multimedia pembelajaran memiliki keunggulan yang menonjol dibandingkan media-media lain yaitu dari sisi interaktivitas, karena multimedia pembelajaran dapat menyajikan materi dengan teks, gambar, suara, animasi, maupun video [6]. Alat bantu berupa aplikasi multimedia pembelajaran dapat menguntungkan pengajar maupun siswa dalam proses belajar mengajar karena dapat mendukung interaksi dalam proses belajar mengajar. Alat bantu berupa aplikasi multimedia pembelajaran tersebut dapat digunakan sebagai media pembelajaran untuk membantu proses belajar mengajar dan diharapkan dapat mengatasi permasalahan yang ada. 


\section{METODOLOGI PENELITIAN}

Langkah-langkah yang digunakan dalam melakukan penelitian mengikuti metode waterfall. Langkah pertama dimulai dengan mengumpulkan data. Pengumpulan data dilakukan dengan cara wawancara dan mempelajari bukubuku referensi yang terkait. Objek yang digunakan dalam penelitian sebagai sumber data adalah sebuah SMK di Surabaya. Wawancara dilakukan dengan tiga orang guru pengajar fisika dan lima orang siswa SMK tersebut. Hasil yang telah dikumpulkan akan digunakan untuk merangkum permasalahan yang ada dan menentukan kebutuhan sistem yang akan dibuat.

Berdasarkan kebutuhan sistem yang telah dirumuskan, dilakukan desain sistem pembelajaran Elektromagnetik. Aplikasi pembelajaran didesain khususnya untuk membantu guru mengajar dan siswa belajar secara mandiri materi Elektromagnetik. Ada empat macam desain yang dibuat, yaitu: materi, data, interface flow diagram, dan user interface. Hasil desain akan diimplementasikan dengan menggunakan beberapa macam Software. Software yang digunakan untuk pembuatan aset yang akan dipakai dalam penyampaian materi dan user interface adalah Adobe Illustrator CS6. Aplikasi pembelajaran dibuat dengan menggunakan software Adobe Flash CS6. Sedangkan pengolahan audio dilakukan dengan menggunakan Adobe Audition CS6.

Sebelum aplikasi diujicobakan kepada pengguna, dilakukan verifikasi untuk memastikan bahwa aplikasi bebas dari error. Apabila didapati adanya error saat verifikasi, maka akan dilakukan perbaikan dan setelah itu dilakukan verifikasi ulang. Verifikasi berakhir apabila sudah tidak didapati adanya error. Setelah verifikasi selesai dilakukan, berikutnya dilakukan validasi. Validasi dilakukan untuk memastikan bahwa aplikasi yang dibuat sudah sesuai dengan kebutuhan pengguna. Pertama kali, validasi dilakukan kepada tiga guru fisika SMK - guru yang sama dengan saat wawancara pertama. Validasi terhadap guru dilakukan dengan meminta ketiga guru untuk mencoba aplikasi, setelah itu menjawab beberapa pertanyaan terkait dengan permasalahan yang dirangkum sebelumnya. Kedua, validasi dilakukan kepada dua puluh siswa SMK ' $X$ ' kelas sebelas, yaitu siswa yang mendapat materi Elektromagnetik. Pemilihan siswa dilakukan dengan menggunakan teknik cluster sampling. Validasi kepada siswa dilakukan dalam dua tahap, yaitu tahap sebelum menggunakan aplikasi dan setelah menggunakan aplikasi. Pada tahap pertama dilakukan pre-test, yaitu: siswa diminta untuk mengerjakan sepuluh soal pilihan ganda. Siswa yang mengikuti pre-test sebelumnya sudah menerima materi Elektromagnetik dari guru pengajar lewat proses pembelajaran reguler. Hal ini dimaksudkan untuk mengetahui kemampuan siswa sebelum menggunakan aplikasi. Setelah itu, siswa diminta belajar melalui aplikasi yang telah dibuat dalam waktu 60 menit. Berikutnya, dilakukan post-test, yaitu mengerjakan sepuluh soal pilihan ganda. Soal yang digunakan dalam pre-test dan post-test diambil secara acak dari bank soal sehingga soal yang diberikan pada pre-test dapat berbeda dengan soal post- test namun mempunyai bobot yang sama. Bank soal dibuat oleh para guru fisika SMK ' $X$ ' dan mengambil dari beberapa buku teks yang ada. Setelah mengerjakan post-test, siswa diminta untuk mengisi kuisioner terkait dengan kemanfaatan aplikasi.

\section{HASIL DAN PEMBAHASAN}

Berdasarkan hasil wawancara dengan tiga orang pengajar Fisika pada SMK ' $X$ ', diperoleh informasi bahwa materi elektromagnetik merupakan materi wajib untuk semua jurusan di SMK ' $X$ ' karena materi ini tergolong sebagai materi fisika dasar. Saat ini, materi diberikan kepada siswa dengan cara menggunakan media elektronik, buku teks, papan tulis, serta alat peraga. Media elektronik yang digunakan adalah power point dan "Aplikasi Sumber Belajar". Power point berisi rangkuman materi dari buku teks yang disampaikan lewat teks dan gambar. "Aplikasi Sumber Belajar" diproduksi oleh Kreasi Lebah Multimedia yang merupakan karya Musyawarah Guru Mata Pelajaran (MGMP), yaitu perkumpulan para guru di Surabaya. "Aplikasi Sumber Belajar" mulai digunakan pada tahun 2013 hingga saat ini [3].

“Aplikasi Sumber Belajar" terdiri dari lima menu, yaitu Home, Tentang Aplikasi, Materi, Bantuan, dan Keluar. Tampilan halaman Home dapat dilihat pada Gambar 1. Halaman Tentang Aplikasi berisi penjelasan mengenai target pengguna aplikasi, tujuan pembuatan aplikasi, dan produser. Menu materi terbagi menjadi lima submenu, yaitu konsep induksi elektromagnetik, aplikasi induksi elektromagnetik, induktor, rangkaian arus bolak balik, dan evaluasi. Empat submenu pertama berfungsi untuk menjelaskan materi dan submenu terakhir berfungsi untuk mengevaluasi kemampuan siswa. Contoh halaman materi Konsep Induksi Elektromagnetik dapat dilihat pada Gambar 2. Contoh halaman submenu Evaluasi dapat dilihat pada Gambar 3 dan Gambar 4. Gambar 3 menunjukkan contoh satu soal tes dari sepuluh soal yang diberikan secara acak, sedangkan Gambar 4 menunjukkan pembahasan soal tes. Menu Bantuan berisi penjelasan tentang fungsi masing-masing icon Yang digunakan dalam aplikasi. Sedangkan menu Keluar digunakan untuk keluar dari aplikasi. Selama aplikasi dijalankan, terdengar suara musik yang diulang-ulang.

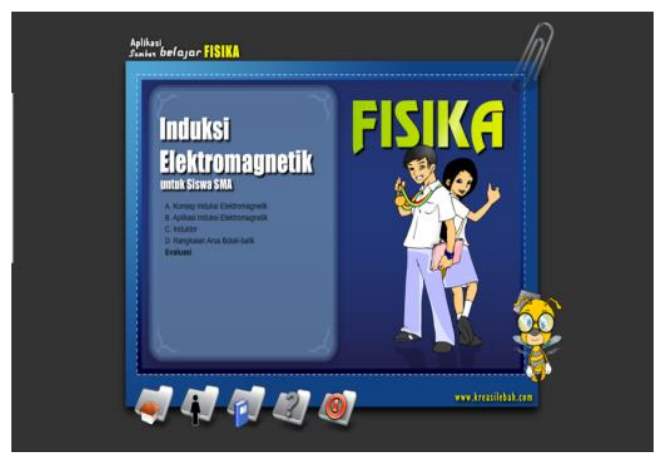

Gambar 1. Halaman Awal "Aplikasi Sumber Belajar” 


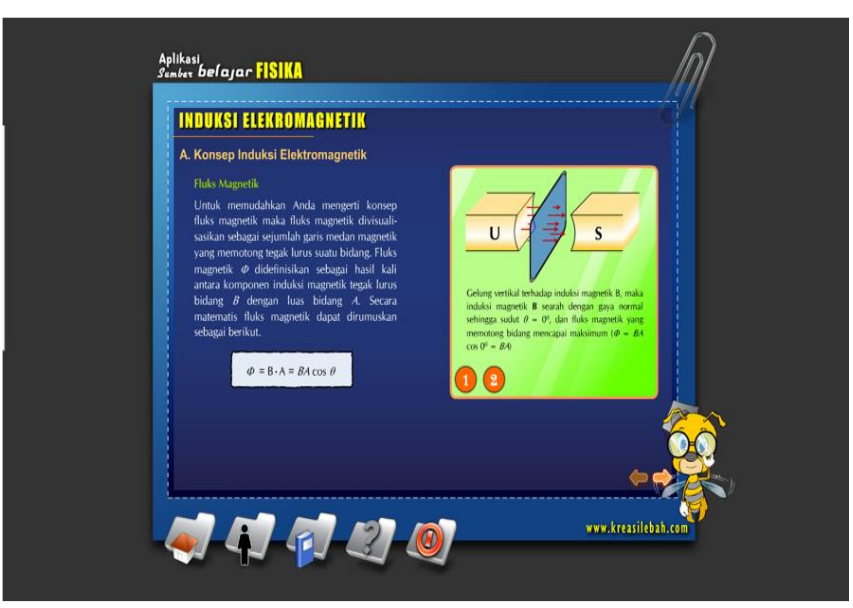

Gambar 2. Halaman Materi Konsep Induksi Elektromagnetik

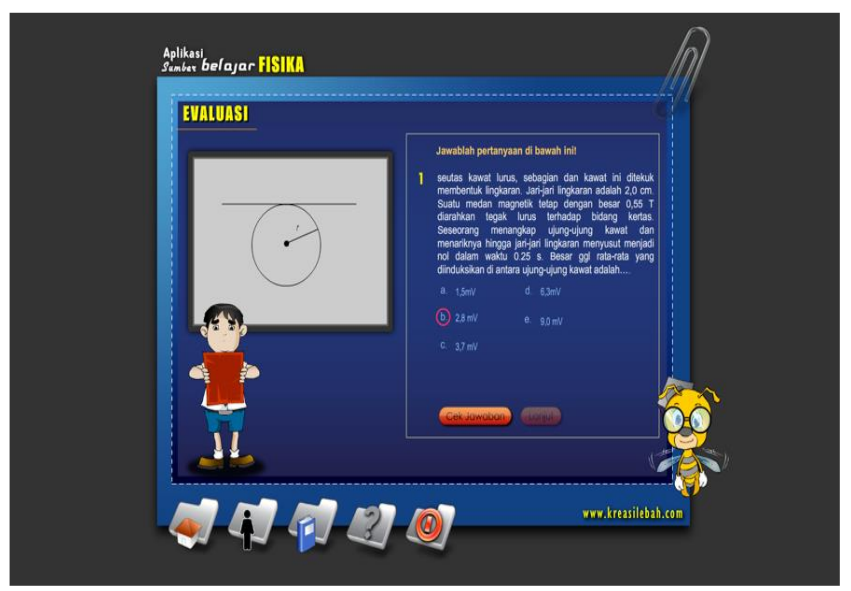

Gambar 3. Halaman Evaluasi

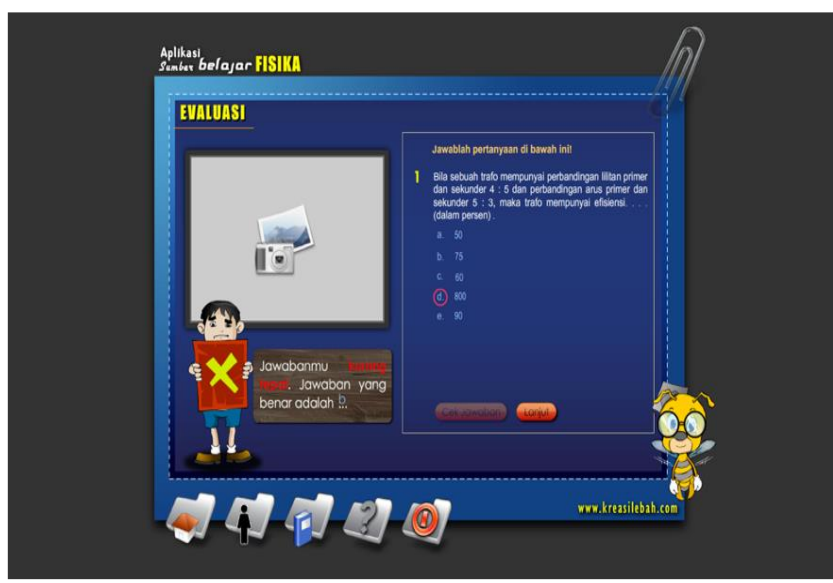

Gambar 4. Halaman Cek Jawaban Evaluasi

Berdasarkan hasil wawancara dengan para guru pengajar fisika, dapat disimpulkan bahwa media yang digunakan dalam proses belajar mengajar selama ini dirasa masih kurang membantu untuk dapat menarik minat siswa untuk belajar materi Elektromagnetik. Hal ini dikarenakan materi
Elektromagnetik dianggap abstrak oleh kebanyakan siswa. Kebanyakan siswa masih belum memahami kegunaan dan cara kerja elektromagnetik di kehidupan sehari-hari. Penggunaan power point, papan tulis, dan buku teks dalam bentuk teks dan gambar dirasa kurang dapat menunjukkan cara kerja elektromagnetik. Aplikasi multimedia yang adapun kurang membantu karena animasi yang digunakan dalam aplikasi dirasa belum tepat sasaran. Animasi yang digunakan hanya berupa tanda panah yang bergerak tanpa adanya penjelasan. Sedangkan alat peraga yang dirasa dapat membantu hanya tersedia dalam jumlah yang terbatas. Hal ini mengakibatkan penggunaan alat peraga dilakukan secara berkelompok dan hanya dalam satu kali pertemuan saja, akibatnya beberapa siswa kurang fokus dalam mempelajari materi bahkan menjadi pengganggu bagi siswa lainnya.

Proses belajar mengajar selain melibatkan guru juga melibatkan siswa. Untuk itu selain dilakukan wawancara dengan guru, juga dilakukan wawancara dengan siswa. Melalui wawancara ini diharapkan dapat diketahui lebih dalam lagi kendala dari sisi siswa saat mempelajari materi elektromagnetik. Berdasarkan hasil wawancara dengan siswa diketahui bahwa alat peraga sangat diharapkan untuk memahami materi elektromagnetik. Namun karena persediaan yang terbatas tidak semua siswa dapat praktek secara langsung. Selain itu, para siswa berharap dalam materi yang disampaikan diberikan contoh-contoh pemanfaatan elektromagnetik dalam kehidupan sehari-hari dalam bentuk praktek langsung.

Berdasarkan permasalahan yang ada, dapat disimpulkan bahwa pengguna membutuhkan sebuah sistem yang dapat menjelaskan materi bukan hanya dalam bentuk teks dan gambar, tetapi dilengkapi dengan animasi sehingga membantu siswa untuk dapat membayangkan cara kerja elektromagnetik. Animasi ditampilkan lengkap dengan penjelasannya sehingga tidak perlu bolak-balik ke halaman teori untuk melihat kaitannya. Sistem perlu dilengkapi dengan contoh-contoh pemanfaatan elektromagnetik yang sering dijumpai dalam kehidupan sehari-hari sehingga dapat membantu siswa untuk lebih mengenai manfaat elektromagnetik. Selain itu, sistem memungkinkan setiap siswa untuk mencoba langsung alat-alat peraga dan berlatih soal secara mandiri sehingga membantu untuk lebih memahani materi elektromagnetik.

Untuk memenuhi kebutuhan pengguna, maka pada penelitian ini dibuat sebuah aplikasi pembelajaran Elektromagnetik. Aplikasi dirancang menjadi tiga bagian besar, yaitu materi, praktikum, dan evaluasi. Materi dibagi menjadi tiga bagian, yaitu Gaya Gerak Listrik (GGL) induksi, fluks magnet, dan aplikasi elektromagnetik dalam kehidupan sehari-hari. Materi akan dijabarkan dalam bentuk tulisan, gambar, suara, serta animasi. Animasi pada materi diberikan saat menjelaskan percobaan Faraday. Melalui animasi ini diharapkan siswa dapat membayangkan sehingga memahami bagaimana elektromagnetik terbentuk. Materi aplikasi elektromagnetik dalam kehidupan sehari-hari dibagi menjadi tiga, yaitu: trafo, motor listrik, dan alat ukur listrik. Ketiga contoh tersebut akan dijabarkan melalui tulisan, gambar, dan animasi cara kerja masing-masing alat untuk 
memudahkan siswa membayangkan bagaimana materi elektromagnetik dapat diaplikasikan oleh siswa di kehidupan sehari-hari. Pada bagian praktikum, siswa dapat praktek secara mandiri dengan menggunakan alat peraga visual.
Selain itu, siswa dapat berlatih lewat bagian evaluasi. Secara lengkap Interface Flow dari aplikasi dapat dilihat pada Gambar 5 [3].

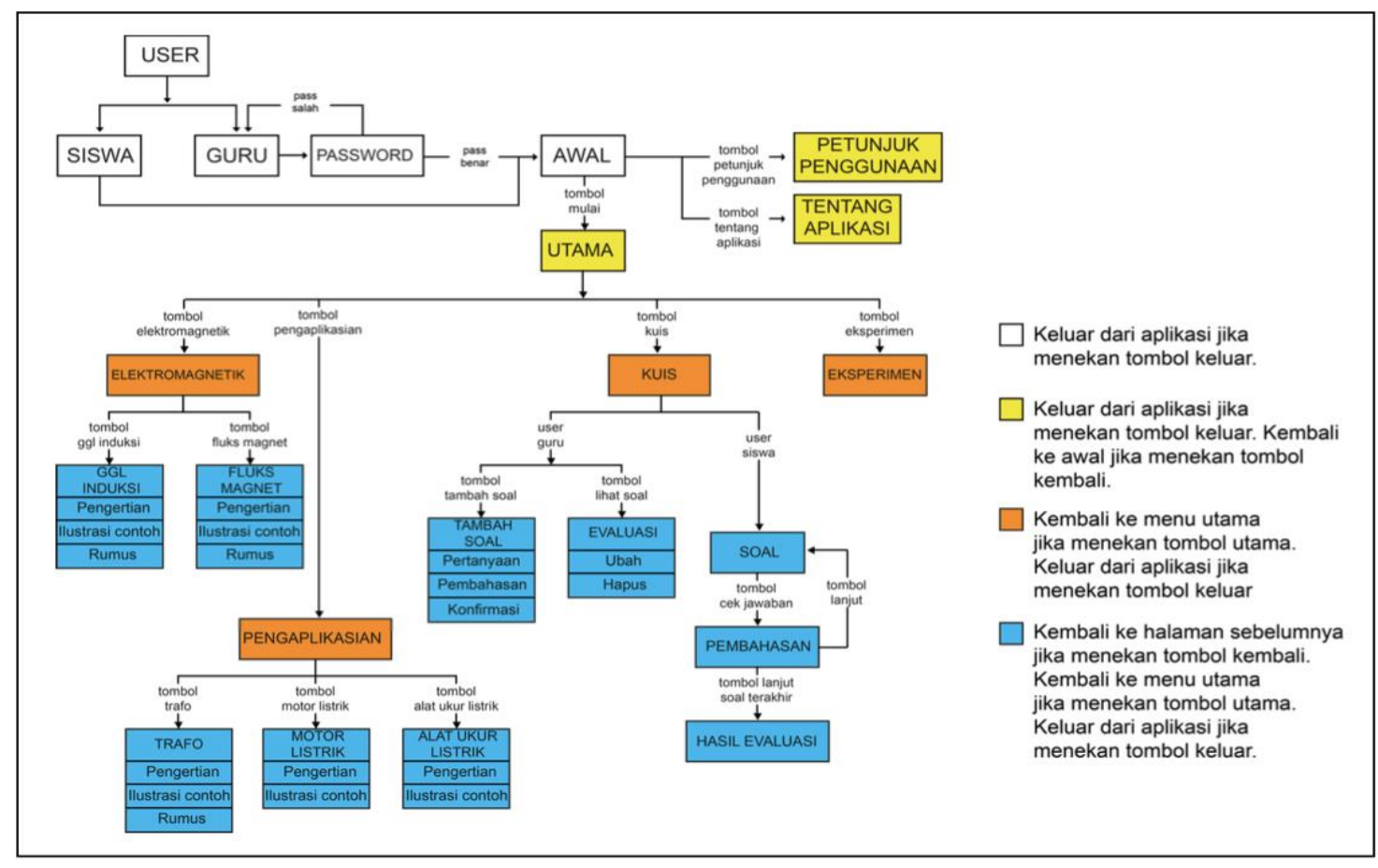

Gambar 5. Interface Flow Diagram Aplikasi Pembelajaran Elektromagnetik

Aplikasi pembelajaran ini mencakup sepuluh screen, yaitu Screen User, Screen Awal, Screen Petunjuk Penggunaan, Screen Tentang Aplikasi, Screen Utama, Screen Elektromagnetik, Screen Pengaplikasian, Screen Eksperimen, Screen Kuis Guru, dan Screen Kuis Siswa. Screen User adalah halaman pertama yang akan muncul secara otomatis ketika aplikasi dijalankan. Halaman ini akan menampilkan judul aplikasi, dua tombol user, yaitu guru dan siswa, dan tombol keluar untuk keluar aplikasi. Jika tombol siswa ditekan, maka aplikasi akan membuka Screen Awal. Jika tombol guru ditekan, ada password yang harus diinputkan supaya aplikasi dapat menampilkan Screen Awal. Screen Awal adalah halaman yang berisi menampilkan judul aplikasi, informasi user mana yang mengakses aplikasi, tombol mulai untuk masuk ke Screen Utama, tombol petunjuk penggunaan untuk masuk ke Screen Petunjuk Penggunaan, tombol tentang aplikasi untuk masuk ke Screen Tentang Aplikasi, dan tombol keluar untuk keluar dari aplikasi.

Saat aplikasi dimulai, Screen Utama akan ditampilkan. Pada halaman ini, akan ditampilkan menu-menu utama yang dapat diakses oleh user. Menu-menu tersebut antara lain, menu elektromagnetik yang akan masuk ke Screen Elektromaknetik, menu pengaplikasian elektromagnetik yang akan masuk ke Screen Pengaplikasian, menu eksperimen yang akan masuk ke Screen Eksperimen, dan menu kuis yang akan masuk ke Screen Kuis, di mana menu- menu tersebut ditampilkan sebagai tombol pada halaman ini. Pada Screen Elektromagnetik, submenu GGL Induksi akan ditampilkan dimana menu-menu tersebut dapat mengakses halaman GGL Induksi, dan submenu Fluks Magnetik yang mengakses halaman Fluks Magnet. Sama halnya dengan menu Elektromagnetik, ketika Screen Pengaplikasian dipilih, user akan menjumpai submenu, yaitu menu Trafo, menu Motor Listrik, dan menu Alat Ukur Listrik. Jika menu Eksperimen dipilih, aplikasi akan menampilkan Screen Eksperimen yang berisi alat peraga yang dapat digerakkan untuk melakukan eksperimen terhadap materi elektromagnetik. Jika menu Kuis dipilih, aplikasi akan menampilkan Screen Kuis. Screen Kuis terbagi menjadi dua jenis, yaitu kuis guru dan kuis siswa. Ketika user masuk aplikasi sebagai guru, maka pada menu Kuis aplikasi akan menampilkan Screen Kuis Guru, di mana user dapat menambah, mengubah, atau menghapus soal evaluasi serta melihat daftar soal evaluasi. Pada Screen Kuis Siswa, user akan mengerjakan sepuluh soal evaluasi secara acak dan aplikasi akan menampilkan nilai user pada akhir kuis. Pada setiap halaman aplikasi, akan diberikan tombol dengan ikon panah ke kiri untuk kembali ke menu sebelumnya, tombol dengan ikon rumah untuk kembali ke menu utama, dan tombol dengan ikon suara untuk mematikan atau menghidupkan suara musik background.

Pembuatan aset multimedia diimplementasikan dengan menggunakan beberapa software antara lain Adobe 
Illustrator CS6 yang digunakan untuk membuat aset yang akan dipakai dalam penyampaian materi dan user interface. Pembuatan aset navigasi dapat dilihat pada Gambar 6 . Pembuatan aset gambar dapat dilihat pada Gambar 7, sedangkan pembuatan aset karakter dapat dilihat pada Gambar 8.

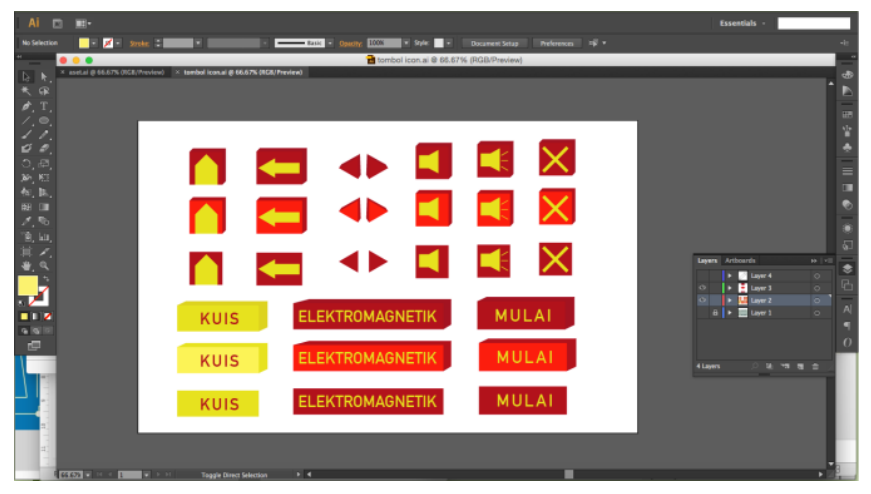

Gambar 6. Pembuatan Aset Navigasi

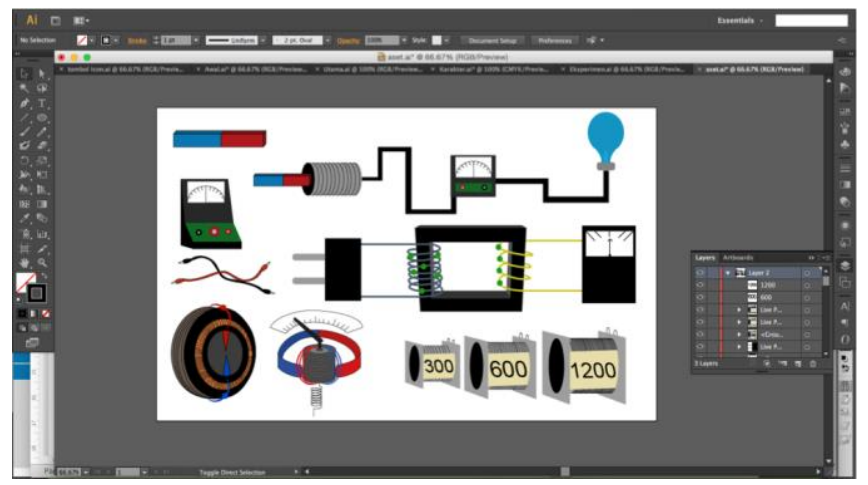

Gambar 7. Pembuatan Aset Gambar

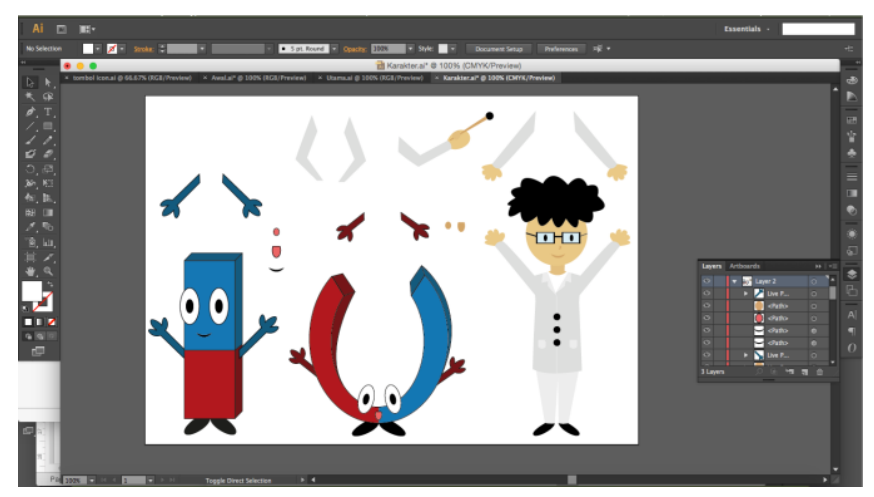

Gambar 8. Pembuatan Aset Karakter

Aplikasi pembelajaran dan animasi dibuat dengan menggunakan software Adobe Flash CS6 yang proses implementasinya ditunjukkan pada Gambar 9 \& Gambar 10. Sedangkan pengolahan audio dilakukan dengan menggunakan Adobe Audition CS6 yang prosesnya dapat dilihat pada Gambar 11 .

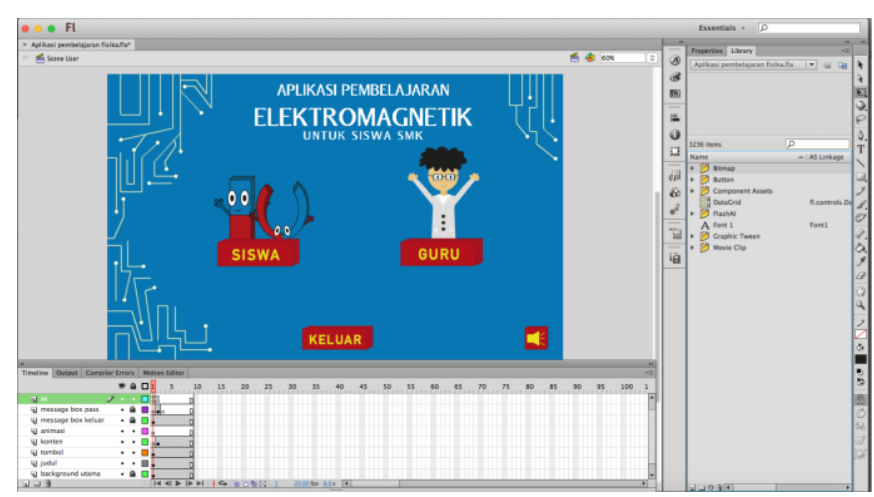

Gambar 9. Pembuatan Aplikasi Pembelajaran

Data yang digunakan dalam penelitian ini adalah data untuk menyimpan soal evaluasi sebagai bank soal dan data pengguna. Soal evaluasi akan ditampilkan dalam bentuk pilihan berganda dengan satu jawaban benar. Pengguna aplikasi dibedakan menjadi dua, yaitu: guru dan siswa. Perbedaan antara guru dengan siswa adalah guru dapat menambahkan soal baru sedangkan siswa tidak dapat. Halaman utama aplikasi dapat dilihat pada Gambar 12 [3].

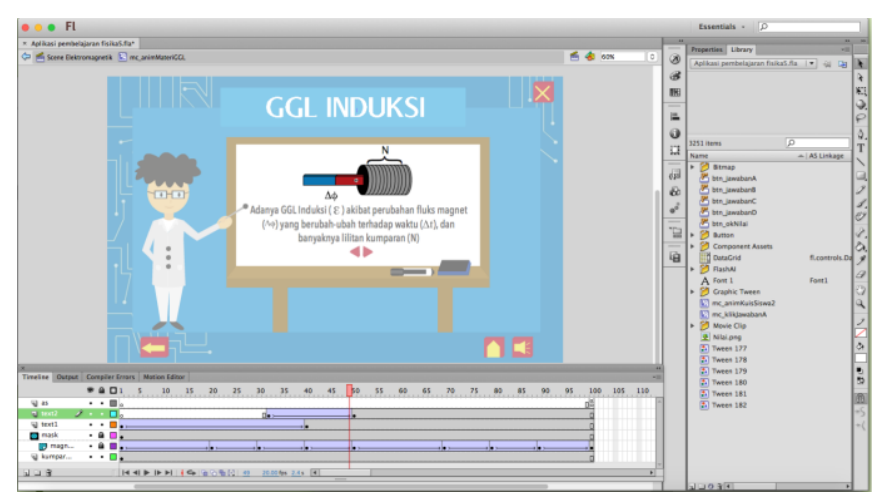

Gambar 10. Proses Animasi

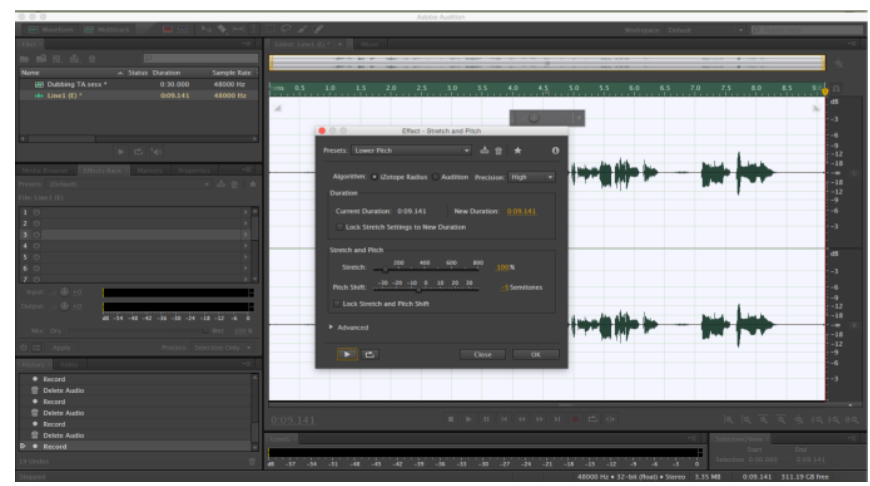

Gambar 11. Proses Pengolahan Audio

Sebelum memulai pembelajaran, sebaiknya pengguna membaca "Petunjuk Penggunaan" terlebih dahulu agar lebih lancar dalam menjalankan aplikasi. Apabila siswa sudah siap untuk belajar, maka siswa dapat masuk ke halaman awal 
Materi, seperti yang terlihat pada Gambar 13 [3]. Contoh halaman materi dapat dilihat pada Gambar 14 [3]. Pada Gambar 8, terlihat beberapa contoh materi GGL induksi dan fluks magnet yang disajikan dalam bentuk tulisan, gambar, suara disertai dengan animasi untuk memperjelas bagaimana elektromagnetik terbentuk dan penggunaan rumus-rumus yang ada. Gambar 15 menunjukkan contoh penjelasan mengenai aplikasi elektromagnetik dalam kehidupan seharihari [3].

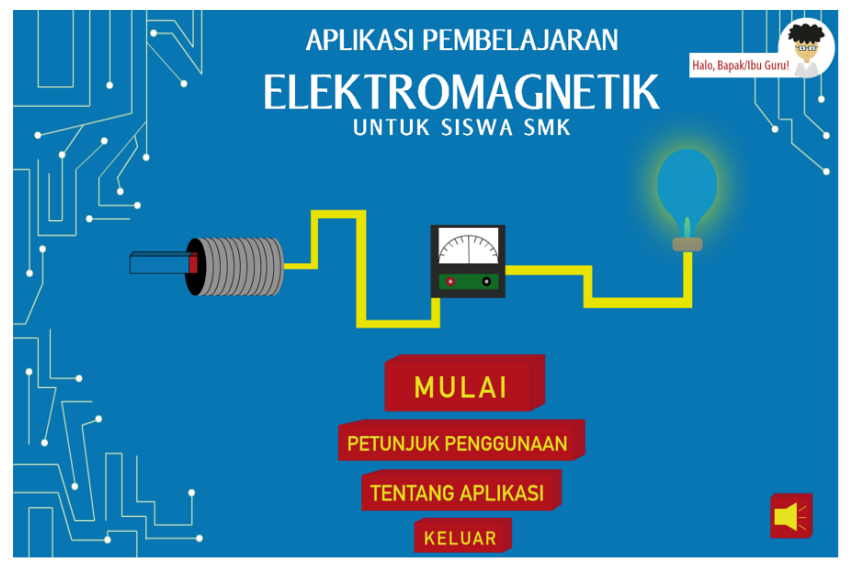

Gambar 12. Halaman Utama Aplikasi

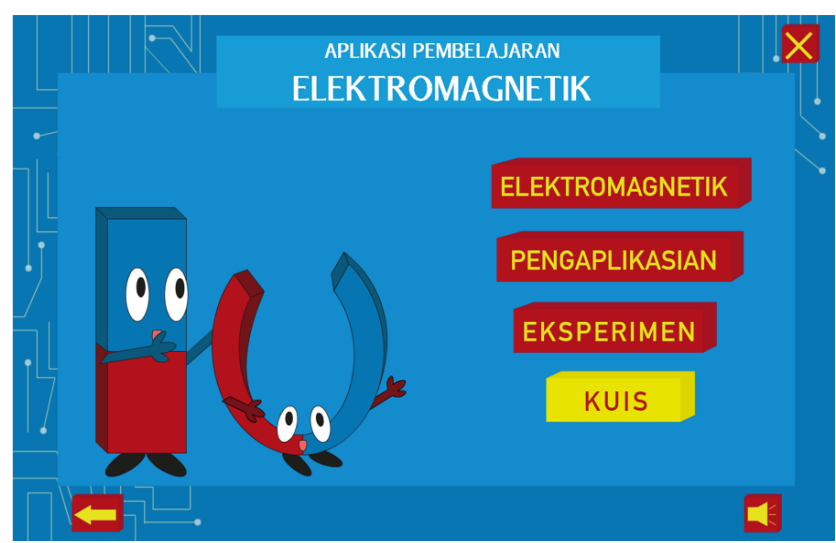

Gambar 13. Halaman Awal Materi

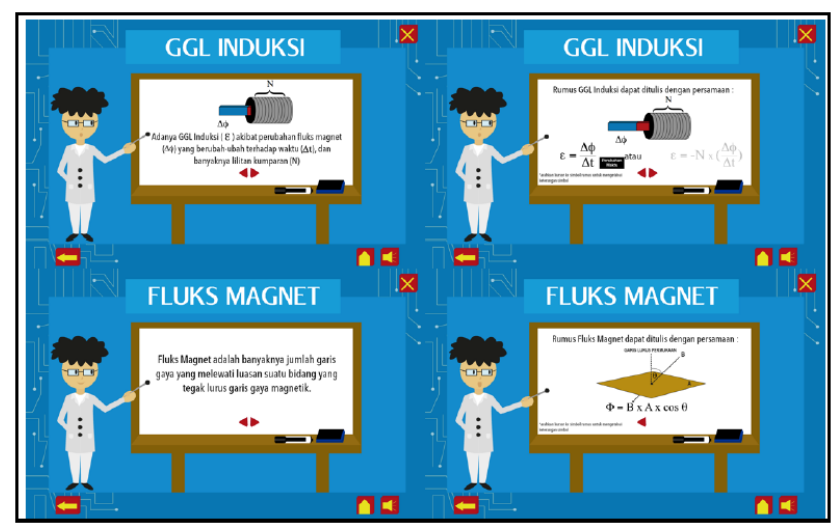

Gambar 14. Halaman Materi
Siswa dapat melakukan praktikum dengan alat peraga secara mandiri melalui halaman Eksperimen, seperti yang ditunjukkan oleh Gambar 16 [3]. Siswa dapat menentukan alat yang akan digunakan dan memasang alat tersebut dengan benar serta memberikan input berupa besarnya fluks magnet yang digunakan. Jika alat yang digunakan terpasang dengan lengkap dan benar, maka saat siswa menggerakan magnet, siswa dapat melihat bagaimana GGL induksi dihasilkan dan perubahan besarnya GGL induksi yang dihasilkan.

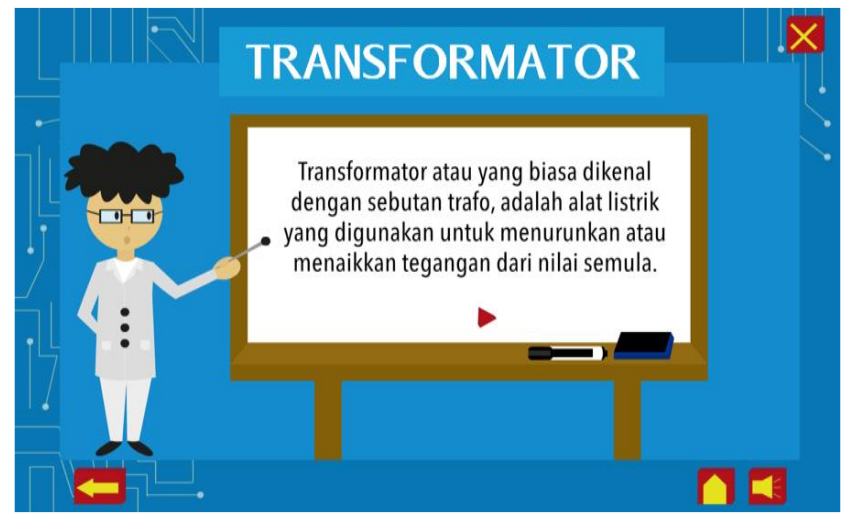

Gambar 15. Halaman Aplikasi dalam Kehidupan Sehari-hari - Transformator

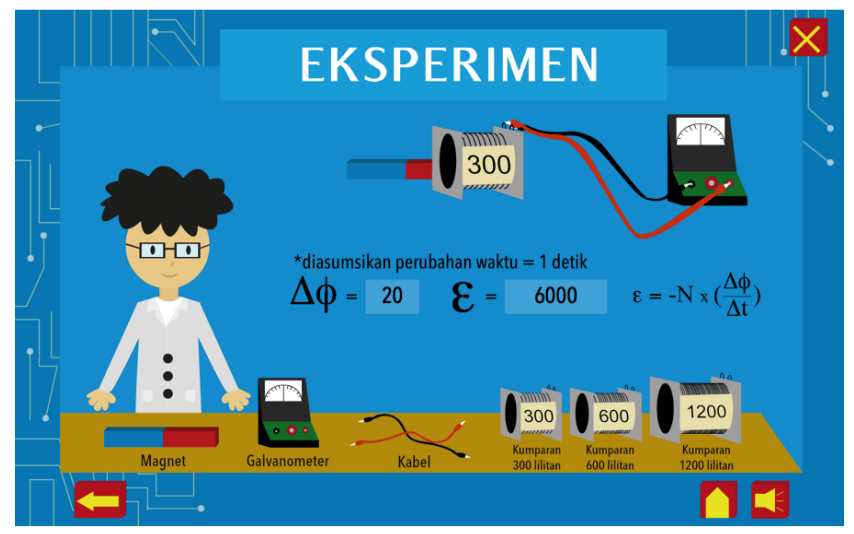

Gambar 16. Halaman Praktikum Mandiri

Siswa dapat mengukur tingkat pemahaman dirinya akan materi melalui halaman Kuis Siswa, lihat Gambar 17 [3]. Melalui halaman ini, siswa dapat berlatih dengan sepuluh soal yang diberikan secara acak dari bank soal. Contoh soal kuis dapat dilihat pada Gambar 18 [3]. Setelah kuis selesai dilakukan siswa akan mendapatkan feedback berupa berapa soal yang berhasil dijawab dengan benar dan pembahasan dari tiap soal jika dibutuhkan. 


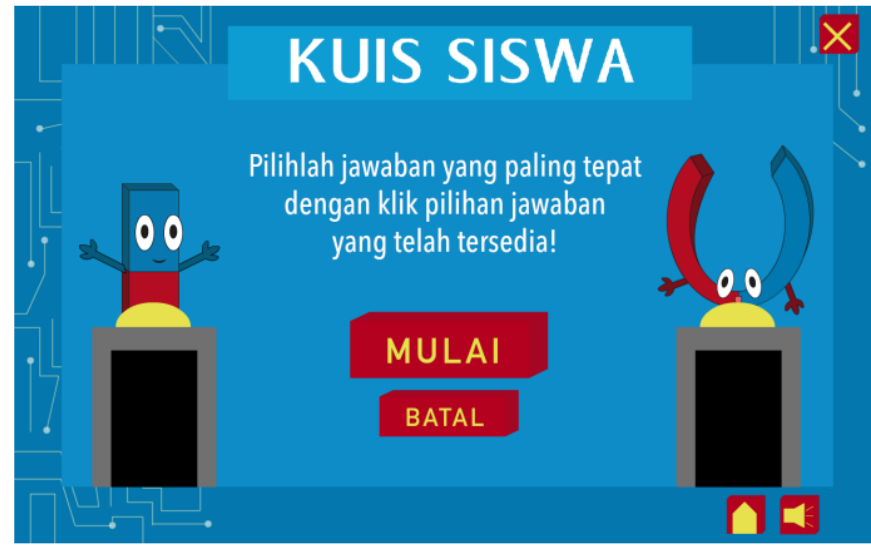

Gambar 17. Halaman Awal Kuis Siswa

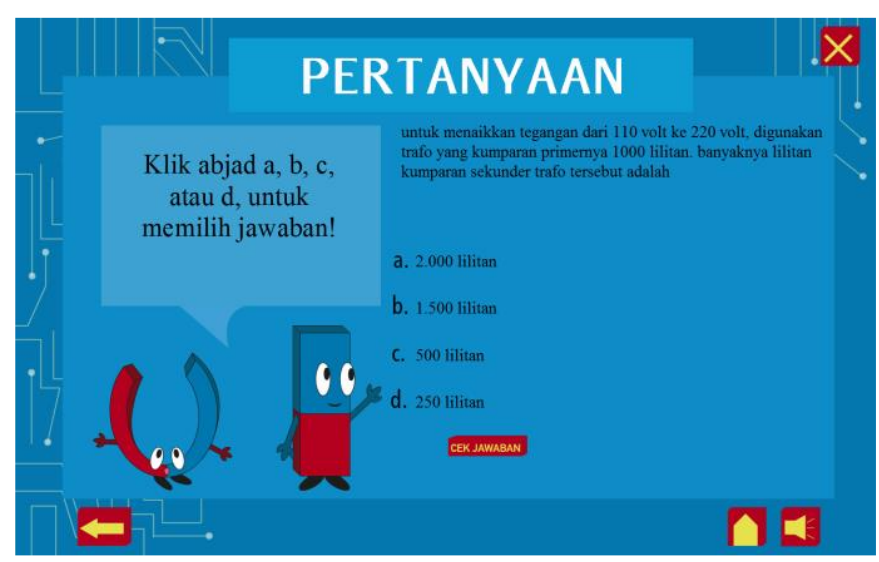

Gambar 18. Halaman Pertanyaan

Guru dapat menambah bank soal melalui halaman Data Soal Quiz, lihat Gambar 19 [3]. Setiap pertanyaan diinput dengan empat pilihan jawaban, satu jawaban benar dan pembahasan, lihat Gambar 20 [3]. Adanya fasilitas untuk menambah bank soal membuat soal-soal yang digunakan siswa untuk berlatih tidak monoton.

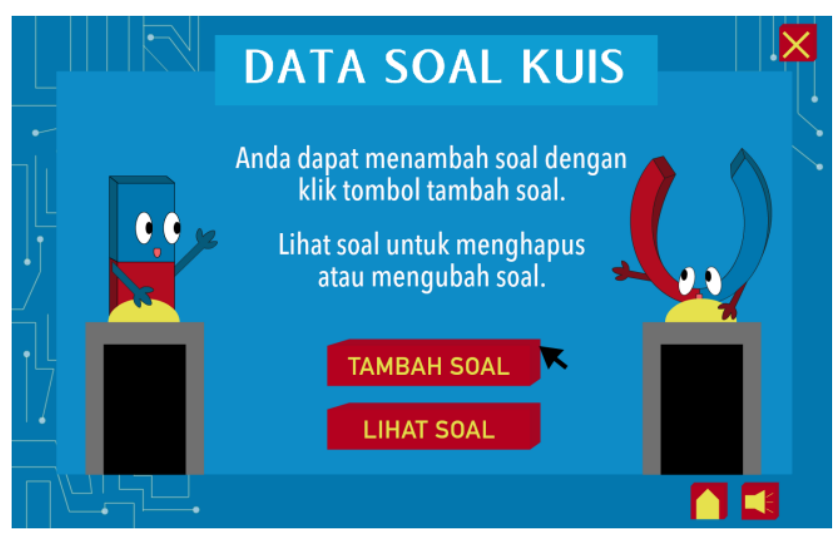

Gambar 19. Halaman Awal Tambah Soal Kuis

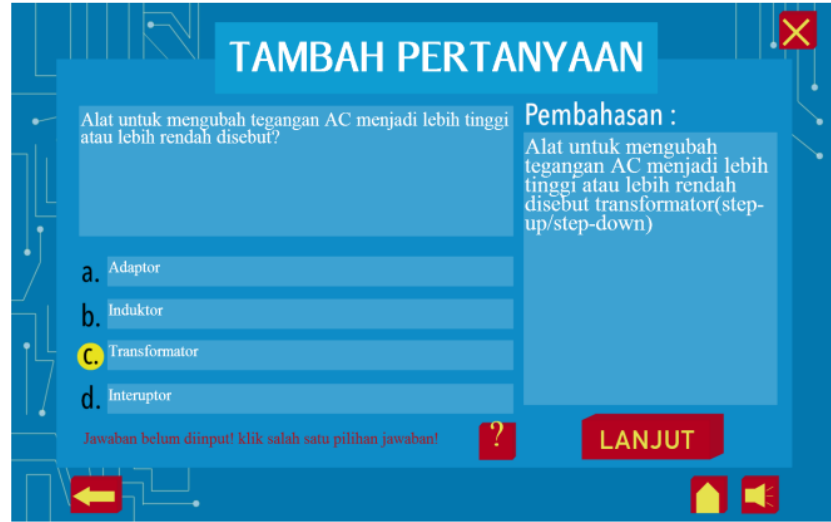

Gambar 20. Halaman Tambah Pertanyaan

Hasil validasi terhadap tiga orang guru pengajar menunjukkan bahwa materi Elektromagnetik yang diberikan dalam aplikasi sudah lengkap, terutama bagian aplikasi dalam kehidupan sehari-hari. Adanya animasi dirasa sangat membantu guru dalam menyampaikan materi kepada siswa khususnya animasi yang menggambarkan bagaimana elektromagnetik terbentuk dan cara kerja alat yang memanfaatkan elektromagnetik. Selain itu, tampilan aplikasi dan navigasi dirasa juga sudah jelas dan mudah dipahami. Namun ada guru yang menyarankan untuk mengembangkan aplikasi ini dalam bentuk 3D dan pembuatan bank soal memungkinkan untuk dilengkapi dengan gambar.

Validasi kepada siswa dilakukan dalam dua tahap, yaitu tahap sebelum menggunakan aplikasi dan setelah menggunakan aplikasi. Pada tahap pertama dilakukan pretest, yaitu: siswa diminta untuk mengerjakan sepuluh soal pilihan ganda yang diambil secara acak dari bank soal. Siswa yang mengikuti pre-test sebelumnya sudah menerima materi Elektromagnetik dari guru pengajar lewat proses pembelajaran reguler. Hal ini dimaksudkan untuk mengetahui kemampuan siswa sebelum menggunakan aplikasi. Setelah itu, siswa diminta belajar melalui aplikasi yang telah dibuat dalam waktu satu jam. Berikutnya, dilakukan post-test, yaitu siswa diminta mengerjakan sepuluh soal pilihan ganda yang dapat berbeda dengan soal pre-test namun mempunyai bobot yang sama karena diambil secara acak dari bank soal. Bank soal dibuat oleh para guru fisika SMK ' $X$ ' dan mengambil dari beberapa buku teks yang ada. Perbandingan nilai hasil pre-test dan post-test siswa dapat dilihat pada Tabel 1 . Tabel 1 menunjukkan bahwa hasil aplikasi dapat meningkatkan minat siswa untuk belajar Elektromagnetik. Hal ini terlihat dari adanya peningkatan sebesar $100 \%$ dari jumlah siswa yang sebelumnya hanya mampu mengerjakan 4 sampai 7 soal pretest menjadi mampu mengerjakan 8 sampai 10 soal post-test.

Setelah siswa mengerjakan soal post-test, siswa diminta untuk mengisi kuisioner terkait dengan kemanfaatan aplikasi. Hasil kuisioner menunjukkan bahwa rata-rata 95\% siswa menyatakan bahwa penjelasan materi, soal-soal kuis dan eksperimen sangat membantu dalam memahami materi elektromagnetik. 
Tabel 1. Hasil Pre-test dan Post-test Validasi Siswa

\begin{tabular}{|c|c|c|c|}
\hline \multirow{2}{*}{$\begin{array}{c}\text { Jumlah Soal } \\
\text { yang Dijawab } \\
\text { dengan Benar }\end{array}$} & \multicolumn{2}{|c|}{ Jumlah Siswa } & \multirow{2}{*}{$\begin{array}{c}\text { Peningkatan } \\
\text { Kemampuan } \\
\text { Memahami } \\
\text { Materi } \\
\text { Elektromagnetik }\end{array}$} \\
\hline & Pre-test & $\begin{array}{c}\text { Post- } \\
\text { test }\end{array}$ & \\
\hline $0-3$ & 0 & 0 & \\
\hline $4-7$ & 12 & 0 & $100 \%$ \\
\hline $8-10$ & 8 & 20 & \\
\hline
\end{tabular}

\section{KESIMPULAN}

Kesimpulan yang dapat diambil dari pemanfaaan multimedia sebagai media pembelajaran ini adalah:

- Pemanfaatan multimedia dalam pembelajaran dapat membantu meningkatkan pemahaman siswa SMK terhadap materi fisika elektromagnetik dan rumus-rumus yang terkait, serta membantu mempermudah membayangkan materi elektromagnetik.

- Aplikasi multimedia pembelajaran dapat membantu pengajar fisika dalam menyampaikan materi karena aplikasi mempunyai animasi yang menjelaskan materi elektromagnetik dan cara kerja pengaplikasian elektromagnetik dalam kehidupan sehari-hari.
- Soal-soal kuis cukup membantu siswa dalam menghafal dan memahami rumus-rumus terkait tentang materi elektromagnetik.

- Aplikasi multimedia pembelajaran berdampak signifikan untuk meningkatkan nilai siswa dalam mengerjakan soalsoal evaluasi.

\section{REFERENSI}

[1] Ruwanto, B. (2007). Asas-Asas Fisika. PT Ghalia Indonesia.

[2] Pauliza, O. (2008). Fisika Kelompok Teknologi dan Kesehatan untuk Sekolah Menengah Kejuruan. Bandung: Grafindo Media Pratama.

[3] Wardani, D. I. K. (2016). Elektromagnetik untuk Siswa SMK. Tugas Akhir. Surabaya: Universitas Surabaya.

[4] Susilana, R. dan Riyana, C. (2009). Media Pembelajaran. Hakikat, Pengembangan, Pemanfaatan, dan Penilaian. Bandung: CV Wacana Prima.

[5] Wibawanto, W. (2017). Desain dan Pemrograman Multimedia Pembelajaran Interaktif. Jember: Penerbit Cerdas Ulet Kreatif.

[6] Oka, G., P., A. (2017). Media dan Multimedia Pembelajaran. Yogyakarta: CV Budi Utama. 